\title{
EFFECT OF WASTE MINERAL ADDITIVES ON FLOW STABILITY OVER TIME IN SELF-COMPACTING CONCRETE MIXES WITH LOW CLINKER CONTENT
}

\author{
Anna M. Grabiec' ${ }^{1}$ Daniel Zawal', Wojciech Kostrzewski' \\ 1 Institute of Construction and Geoengineering, Faculty of Land Reclamation and Environmental Engineering, \\ Poznań University of Life Sciences, 94 Piątkowska St., 60-649 Poznań, Poland, e-mail: agra@up.poznan.pl, \\ danzaw@up.poznan.pl
}

Received: 2015.06.06 Accepted: 2015.08.31 Published: 2015.10.01

\begin{abstract}
Contemporary solutions in concrete technology are varied, and consist in e.g. the use of new generation concretes, including the most spectacular achievement of the 1990s - self-compacting concrete (SCC) being the subject of continuous research, as well as protection of the environment against excessive anthropogenic pressures, such as carbon dioxide which is a major emission substance from the cement industry. The studies analysed the possibilities for replacing part of the clinker binder (cement CEM I 42.5 R) in self-compacting concrete with three types of waste mineral additives: fly ash, limestone powder, and granite powder. Focus was placed on key technological characteristics of concrete mixes: air content and rheological properties, maximal diameter of slump-flow and changes thereof over time, as well as the mix's flow time into the $500 \mathrm{~mm}$ diameter, determining the flow dynamics. 28-day compressive strength of the concrete was recognised as a secondary property which in self-compacting concretes results from achieving the right range of the mix's rheological properties. Concretes were produced using gravel-sand aggregate in 3-fraction composition and a high-efficiency superplasticiser. The studies were conducted as a planned experiment in the 3-ingredient mixes plan.
\end{abstract}

Keywords: self-compacting concrete, waste mineral additive, sustainability of civil engineering.

\section{INTRODUCTION}

Engineering entails a permanent environmental impact. It is, therefore, crucial to seek balance between respecting the environment and achieving the construction goal at the stage of procuring raw materials, designing, completion, and operation [Bromberek 2012]. Sustainable development in engineering can be achieved using various methods, such as involvement of state-of-theart concrete technologies and measures aimed at protecting the environment against excessive anthropogenic pressures, including carbon dioxide which is a major emission substance from the cement industry.

In terms of state-of-the-art technologies, self-compacting concrete (SCC) is unquestionably the most ground-breaking solution of the last twenty five years. It is a cement composite with high compressive strength, tightness and, according to some scientists [e.g. Okamura and Ouchi 2003; Szwabowski and Gołaszewski 2010; Grzeszczyk and Podkowa 2012], higher durability than that of ordinary concretes, as well as tidy surface finishing. These properties are achieved owing to peculiar rheological properties of the concrete mix, its high plastic viscosity and low yield limit [Kurdowski 2010; Szwabowski and Gołaszewski 2010]. Flowability and compactibility of the concrete mix under the gravity forces and self-deaeration depend on proper selection of quality and quantity of concrete ingredients, e.g.: high-efficiency superplasticiser, mineral additive acting as a microfiller (fly ash, granulated blast furnace slag, stone powder) as well as the recommended viscosity modifying agent regulating 
the superplasticiser's effect [Okamura and Ouchi 2003; Szwabowski and Gołaszewski 2010; Woyciechowski 2006; Grabiec 2013].

It is worth mentioning that in the literature, use of certain stone powders (e.g. marble, granite, basalt) in concrete has not found adequate attention. Corinaldesi et al. [2010] stated that because of high fineness of marble powder it was possible to perceive it as a very effective mineral additive in providing very good cohesiveness of cement mortars and concretes. On the contrary, Aruntas et al. [2007] observed decreasing slump flow diameter, associated with increasing the slump flow time of self-compacting mixes when marble powder was used. Nepomuceno et al. [2012] found that in the case of granite powder used as a microfiller for SCC, demand for superplasticiser turned out to be comparable to the results obtained using fly ash and limestone powder. Additionally, consumption of mixing water with additive of granite powder was equal to the consumption of mixing water with cement - only, independent of the percentage of cement replaced by mineral additive. As far as basalt powder as a microfiller in SCC technology is concerned, it was stated by Liu Laibao et al. [2013] that it has obvious potential pozzolanic activity. Therefore, more detailed investigations are certainly required.

Technology of self-compacting concrete eliminates the need for mechanical compaction of the concrete mix, thus reducing the level of noise harmful to the workers and the environment, improving building site safety and saving energy. Filling formworks with the concrete mix, combined with facilitation of this process in structural fragments with difficult or limited access or with congested reinforcement, is more effective, and the rotation of formworks, the entire forming process, and the investment process is, consequently, shorter [Szwabowski and Gołaszewski 2010].

Advantageous technical properties of hardened self-compacting concrete - high compressive strength and, first and foremost, long working life - also meet environmental expectations.

As production of every type of concrete, selfcompacting included, requires the use of cement, it is environmentally burdensome due to carbon dioxide emission. According to IPPC-5 Report [2014], global carbon dioxide emission from anthropogenic sources in 2011 amounted to nearly $32 \mathrm{Gt}$, of which $2.3 \mathrm{Gt}$ was $\mathrm{CO}_{2}$ generated by the cement industry. The anticipated cement production increase by 2030 is estimated at $216 \%$
[WBCSD 2009]. Measures aimed at $\mathrm{CO}_{2}$ emission reduction are, therefore, absolutely necessary. One of these measures is production of cements with low Portland clinker content. These binders are referred to as green cements or ecocements [Aitcin 2000; Meyer 2009; Giergiczny et al. 2010; Kurdowski 2010]. Another measure is replacement, as far as possible, of Portland cement (CEM I) in concrete with waste mineral additives, such as fly ash, granulated blast furnace slag, or stone powders [Takada et al. 1999; Kaszyńska 2003; Felekoğlu et al. 2006; Corinaldesi and Moriconi 2008; Voltz 2010; Grzeszczyk and Podkowa 2012; Samer 2013].

The authors believe that two indexes proposed by Damineli et al. [2010] are well matched with the measures oriented at sustainable development of the cement industry and sustainable development of concrete technology. They determine eco-efficiency of cement binder used for specific technological applications (cement quantity per $1 \mathrm{~m}^{3}$, resulting compressive strength of concrete). These are: binder intensity index $b_{i}$ and carbon intensity index $c_{i}$. The first one describes the cement mass per $1 \mathrm{~m}^{3}$ of concrete necessary to achieve $1 \mathrm{MPa}$ strength, and the one second presents the mass of carbon dioxide emitted in the production process of such a volume of cement that allows the achievement of concrete strength of $1 \mathrm{MPa}$. Hence, the $b_{i}$ index makes it possible to estimate the efficacy of a given cement binder in the process of obtaining strong and durable concrete, while $c_{i}$ index determines the single contribution of the binder to the $\mathrm{CO}_{2}$ emission. If a complementary assessment of the eco-efficiency of cements is to be performed, it is essential to use both indexes simultaneously. As in all processes of concrete production most of the carbon dioxide emission is generated during cement production, the data can be treated as quite a close estimation of this emission for the purposes of producing concrete with specific properties. Obviously, estimations should be carried out on an individual basis since emissivity of $\mathrm{CO}_{2}$ varies between individual cement plants, different raw materials are used to produce clinker, and since selected concrete components vary in terms of quality and quantity depending on the requirements of the project. More precise estimations could be achieved by including the volume of $\mathrm{CO}_{2}$ generated by transport of raw materials and cement as the final product, and by technological operations connected with execution of concrete structures. 
In the light of the indexes proposed by Damineli et al. [2010], replacement of part of cement binder in concrete with waste mineral additives will result in lower $c_{i}$ index compared to the value of $c_{i}$ for pure Portland cements. Based on local and international data, Damineli et al. [2010] estimated that $\mathrm{CO}_{2}$ emission index in the production of pure clinker cements is approximately $4.3 \mathrm{~kg} / \mathrm{MPa}$ and $1.5 \mathrm{~kg} / \mathrm{MPa}$ in the production of cements with mineral additives. The $c_{i}$ index is related to the binder intensity index $b_{i}$ which in concretes with compressive strength exceeding $50 \mathrm{MPa}$ is approximately equal to $5 \mathrm{~kg} /$ $\mathrm{m}^{3} / \mathrm{MPa}$, and for concretes with strength of 20 $\mathrm{MPa}$ is as high as $13 \mathrm{~kg} / \mathrm{m}^{3} / \mathrm{MPa}$. For $\mathrm{CO}_{2}$ emission reduction, $b_{i}$ index is particularly important considering that with its low values (for concretes with lower compressive strength) we can expect longer working life of the structure and, consequently, delayed need for repair, reinforcement, and - in extreme cases - replacement of components, which allows to prevent use of additional binding agents and, thus, additional carbon dioxide emission.

This paper combines two issues that the authors believe may be decisive for mitigating the effects of disturbed environmental balance. It is the use of self-compacting concrete which, as described above, is to a certain extent "green" by definition, and replacement of some pure clinker binder in this concrete with waste mineral additives (fly ash, limestone and granite powders) which help reduce $\mathrm{CO}_{2}$ emissions and are indispensable microfillers in the SCC technology. Focus has been placed on technologically important characteristics of the concrete mix, air content, and rheological properties - maximal diameter of slum-flow and changes thereof over time, as well as the mix's flow time into the $500 \mathrm{~mm}$ diameter, determining the flow dynamics to a certain degree. 28-day compressive strength of the concrete was recognised as a secondary property which in selfcompacting concretes results from achieving the right range of the mixture's rheological properties.

Use of self-compacting concrete as a construction material for hydrotechnical structures, apart from the advantages presented above, may also entail certain additional logistic and economic benefits. It is frequently the case that hydrotechnical structures are located in areas poorly accessible from public roads. The use of self-compacting concrete may eliminate the transport, unloading, and the use of element compacting equipment in such cases. Note, however, that due to peculiar nature of some structures, requiring the use of congested reinforcement, surface vibrators may be the only possible method of concrete compaction. Moreover, hydrotechnical structures can be found within landscape parks (such as Natura 2000 sites) where environmental impact must be as small as possible. In such cases, the number of equipment and noise level must be reduced to the absolute minimum.

\section{MATERIALS AND METHODS}

The Portland cement CEM I $42.5 \mathrm{R}$ was selected to prepare self-compacting mixes. It conformed to the standard EN 197-1:2000. Aggregate mix was composed of two pit sands $(0 / 0.5$ $\mathrm{mm}$ and $0 / 2 \mathrm{~mm})$ and gravel $(2 / 8 \mathrm{~mm})$ coming from local sources. All aggregates complied with requirements of the EN 12620:2002 standard. Fly ash from a CHP (combined heat and power) plant, fulfilling the requirements of the standard EN 450-1:2006, limestone and granite powders were chosen as waste mineral additives also playing the role of microfillers. Stone powders used for the needs of this work, was created in a laboratory way by crushing $5 \mathrm{~kg}$ sample of granite and lime stone coarse aggregate in a laboratory ball grinder for 4 hours. After crushing process both powders were subjected to the sieve test. The part of material passing the $0.045 \mathrm{~mm}$ sieve was used in the study. The superplasticiser with a polycarboxylate basis served as a fluidifying admixture $(\mathrm{pH}-$ 6 , specific density $-1.10 \mathrm{~kg} / \mathrm{dm}^{3}$, solid content $-30 \%$; with recommended dosage $-0.2-1.6 \%$ ).

Concrete mix recipes calculated according to the modified design method presented in the paper of Mądrawski and Kostrzewski [2008] were shown in Table 1. The following ranges concerning the flow time into the $500 \mathrm{~mm}$ diameter $\left(\mathrm{T}_{500}\right)$ and the maximal diameter of slump flow $\left(\mathrm{d}_{\max }\right)$ perceived as rheological properties of self-compacting mixes were adopted for the presented study: $\mathrm{T}_{500}=2-6 \mathrm{~s}$ and $\mathrm{d}_{\max }=760-850 \mathrm{~mm}$ (SF3 class), respectively and according to the recommendations in the sources related to the subject [Szwabowski and Śliwiński 2003; Szwabowski and Gołaszewski 2010; Grabiec 2013].

First, dry ingredients (gravel, sands, mineral additives and cement) were mixed using a paddle type $0.05 \mathrm{~m}^{3}$ laboratory concrete mixer for $1 \mathrm{~min}$ ute. Then water including an appropriate amount 
Table 1. Mix proportioning of various self-compacting concrete mixes

\begin{tabular}{|c|c|c|c|c|c|c|c|}
\hline \multirow[b]{2}{*}{$\begin{array}{l}\text { Designation of } \\
\text { concrete series }\end{array}$} & \multicolumn{7}{|c|}{ Content of concrete mix constituents } \\
\hline & $\begin{array}{l}\text { Cement } \\
{\left[\mathrm{kg} / \mathrm{m}^{3}\right]}\end{array}$ & $\begin{array}{l}\text { Microfiller } \\
{\left[\mathrm{kg} / \mathrm{m}^{3}\right]}\end{array}$ & $\begin{array}{c}\text { Sand } \\
0 / 0.5 \mathrm{~mm} \\
{\left[\mathrm{~kg} / \mathrm{m}^{3}\right]}\end{array}$ & $\begin{array}{c}\text { Sand } \\
0 / 2 \mathrm{~mm} \\
{\left[\mathrm{~kg} / \mathrm{m}^{3}\right]}\end{array}$ & $\begin{array}{l}\text { Gravel } \\
2 / 8 \mathrm{~mm} \\
{\left[\mathrm{~kg} / \mathrm{m}^{3}\right]}\end{array}$ & $\begin{array}{l}\text { Superpla- } \\
\text { sticiser } \\
{\left[\mathrm{dm}^{3} / \mathrm{m}^{3}\right]}\end{array}$ & $\begin{array}{c}\text { Water } \\
{\left[\mathrm{dm}^{3} / \mathrm{m}^{3}\right]}\end{array}$ \\
\hline FA & 350 & 164 & 128 & 385 & 1224 & 10.3 & 147 \\
\hline LP & 350 & 201 & 127 & 380 & 1208 & 11.0 & 154 \\
\hline GP & 350 & 231 & 126 & 377 & 1196 & 12.0 & 160 \\
\hline$F A+L P$ & 350 & 82(FA)+101(LP) & 128 & 383 & 1216 & 10.7 & 150 \\
\hline$F A+G P$ & 350 & $82(F A)+115.5(G P)$ & 127 & 381 & 1210 & 11.0 & 153 \\
\hline$L P+G P$ & 350 & $101(\mathrm{LP})+116(\mathrm{GP})$ & 126 & 379 & 1202 & 11.3 & 157 \\
\hline
\end{tabular}

Note: FA, LP, GP - concrete mixes with $100 \%$ fly ash, limestone and granite powder volumetric content, respectively; FA+LA, FA+LP, LP+GP - concrete mixes with 50\% fly ash and 50\% limestone, 50\% fly ash and 50\% limestone, $50 \%$ limestone and $50 \%$ granite powder volumetric content, respectively.

of superplasticiser was added and mixed for another 4 minutes.

Air content of fresh concrete was tested by a method specified in the standard EN 123507:2009, with a 3-minute break for self-deaereating for each of two placed layers of fresh concrete. Measurements were made immediately after making the mix and after 90 minutes of its preparation. The dynamics of flowing fresh concrete was indicated by measuring the time needed to obtain the flow to $500 \mathrm{~mm}$ diameter of concrete mix. The fluidity of fresh concrete was indicated by measuring flow spread diameter (maximal diameter) in the inverted Abrams cone according to the method specified in the standard EN 12350$8: 2009$. In order to examine the changes in time of dynamics of the flow and the flow value, $T_{500}$ and the flow value were measured immediately after mixing and after: 30, 60 and 90 minutes. One measurement of $T_{500}$ and three of spread diameter for each series were made.

Tests on compressive strength, in compliance with requirements of the EN 12390-3:2009 standard were performed after 28 days on 5 cubic specimens of $150 \times 150 \times 150 \mathrm{~mm}$ dimensions for each series of concrete.

The Statistica (Software program, licence from Poznan University of Life Sciences, license no: JGNP 105B037825 AR-A) was used for the statistical analysis referring to the compressive strength results.

For the mean results of the compressive strength obtained after 28 days, binder and carbon dioxide intensity indexes $\left(b_{i}\right.$ and $\left.c_{i}\right)$ were calculated. In order to calculate a unitary emission for the CEM I 42.5 R cement, 2011 data from one of Polish cement plants were used, assuming the cement content equal to $350 \mathrm{~kg} / \mathrm{m}^{3}$. The calculations included the following cement value, i.e. 739.7 $\mathrm{kg} \mathrm{CO}$ per 1 ton of cement. The emission from combustion of biomass, $5 \%$ of remaining additives according to the EN 197-2:2000 standard and the participation of the setting regulator were not taken into account.

\section{RESULTS AND DISCUSSION}

The flow time into the diameter of $500 \mathrm{~mm}$, the maximal slump flow diameter of concrete mixes and their changes with time are shown in Figures 1, 2, 3 and 4.

The air content in fresh concretes immediately after mixing ingredients and after 90 minutes is shown in Figure 5.

28-day compressive strength $f_{c}$ values are presented in Figure 6. Results of calculations of $b_{i}$ and $c_{i}$ values are given in Table 2 . Finally, the qualitative evaluation for each concrete mix series was made (Table 3 ).

Results of the test of concrete mixes' flow time to the $500 \mathrm{~mm}$ diameter $\left(\mathrm{T}_{500}\right)$ directly following mixing of the ingredients (time ' 0 ') were within the acceptable range of 2-6 seconds. Later during the measurement (90 minutes after mixing of the ingredients - time ' 90 '), differentiation of results could be observed. In the last phase of the tests, the FA-LP mix (fly ash and limestone powder as the microfiller) with flow time to the $500 \mathrm{~mm}$ diameter after 90 minutes was as long as 12 seconds. It is worth noting that the effect of limestone powder on $\mathrm{T}_{500}$ was also rather adverse in combination with GP (granite powder) where this time was 2.5 seconds directly after mixing of the ingredients and 6 seconds after 90 minutes. In the mix containing only limestone powder or 


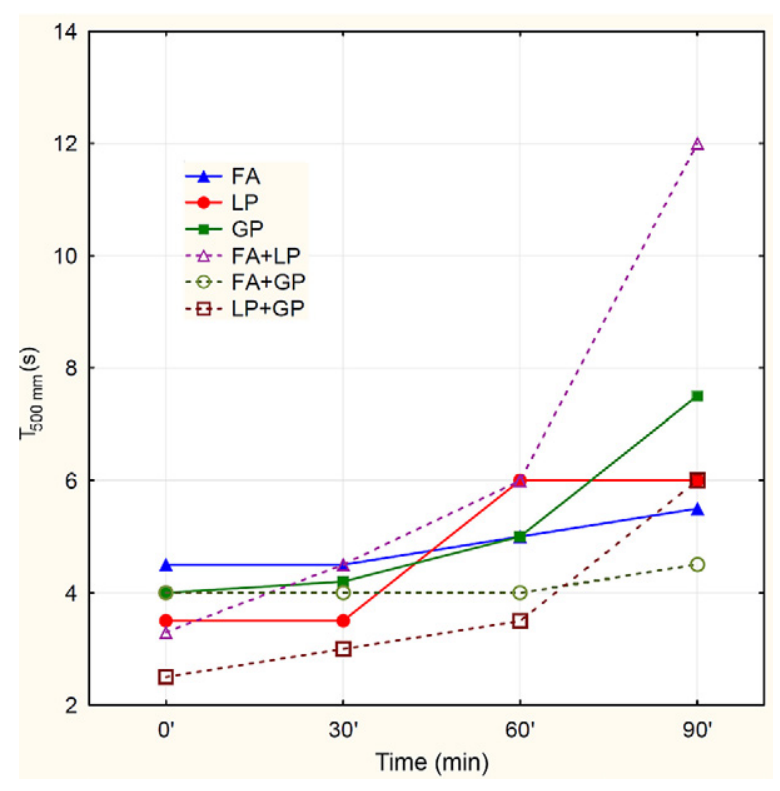

Figure 1. Time of SCC mixes' flow into diameter of $500 \mathrm{~mm}$ versus time only granite powder, differences between $T_{500}$ measured at the beginning (time ' 0 ') and after 90 minutes (time '90') were not that large (Figure 1). It can be, therefore, supposed that the use of LP with other mineral additives may have an adverse effect on the concrete mix's yield limit after a longer time (after 60 minutes).

The analysis of results of the maximal diameter of slum-flow test performed directly after mixing of the ingredients has shown the greatest flow $(810 \mathrm{~mm})$ when limestone powder and granite powder was used, and the smallest $(750 \mathrm{~mm})$ with fly ash used alone. Obviously, the maximal slum-flow of concrete mixes decreased over time, gradually until 60 minutes, and rapidly afterwards. It was the most evident in mixes with fly ash and limestone powder as microfillers, as well as in the mix with limestone powder only, as after 60 minutes differences in maximal slum-flow



Figure 2. Slump flow diameter of SCC mixes immediately after mixing of ingredients (left) and after 30 minutes (right)

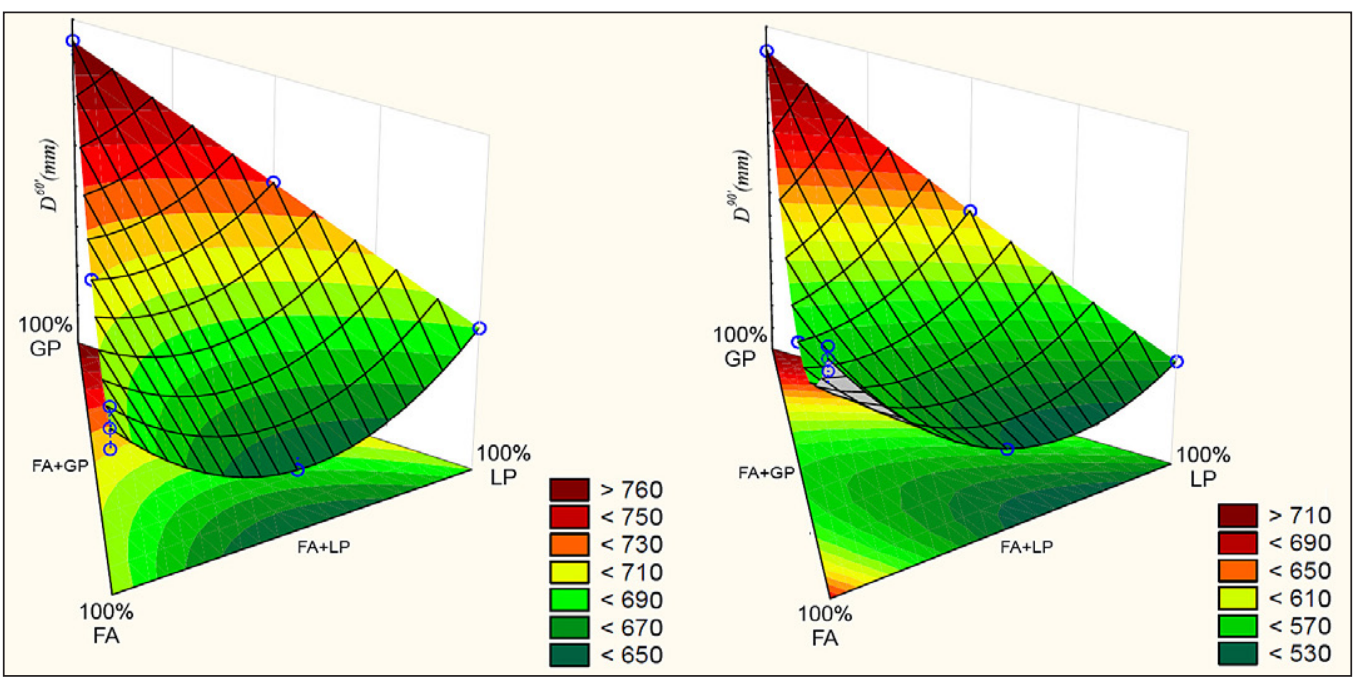

Figure 3. Slump flow diameter of SCC mixes after 60 (left) and 90 (right) minutes 


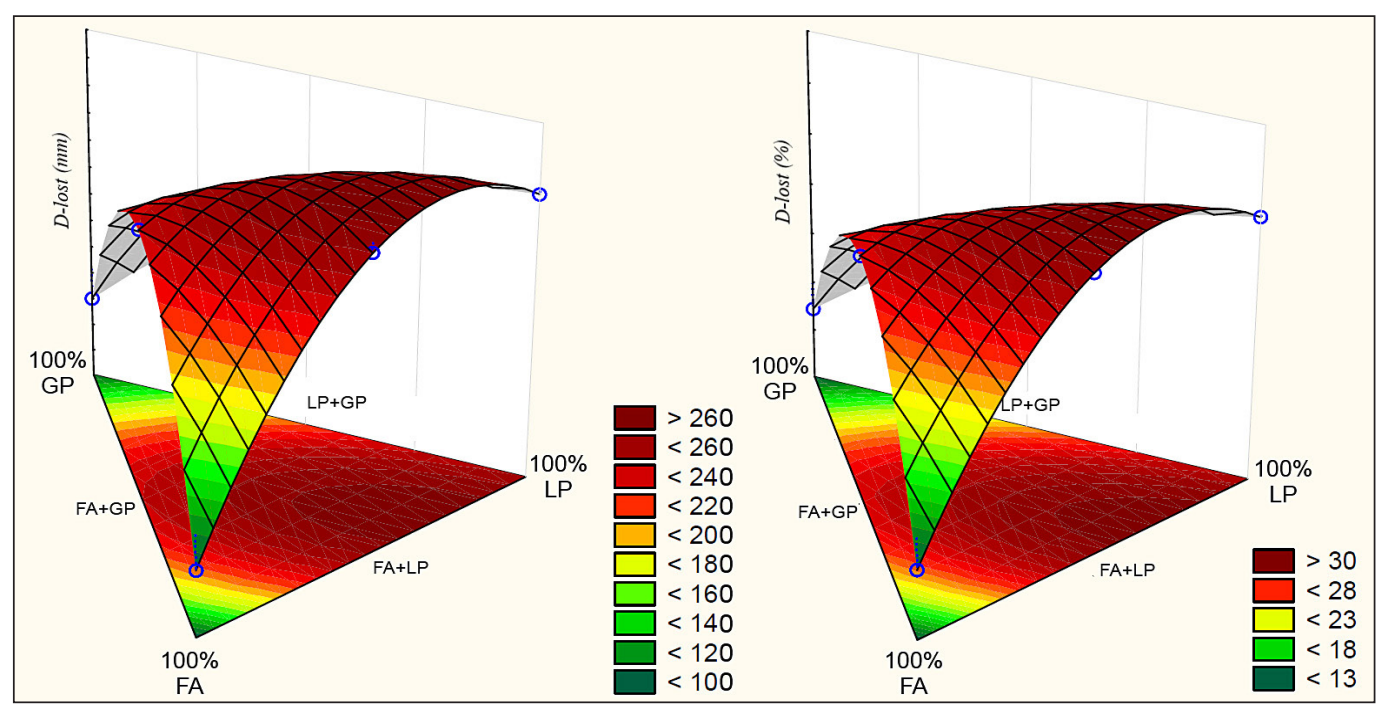

Figure 4. Slump flow diameter lost in mm (left) and in percent (right) of SCC mixes

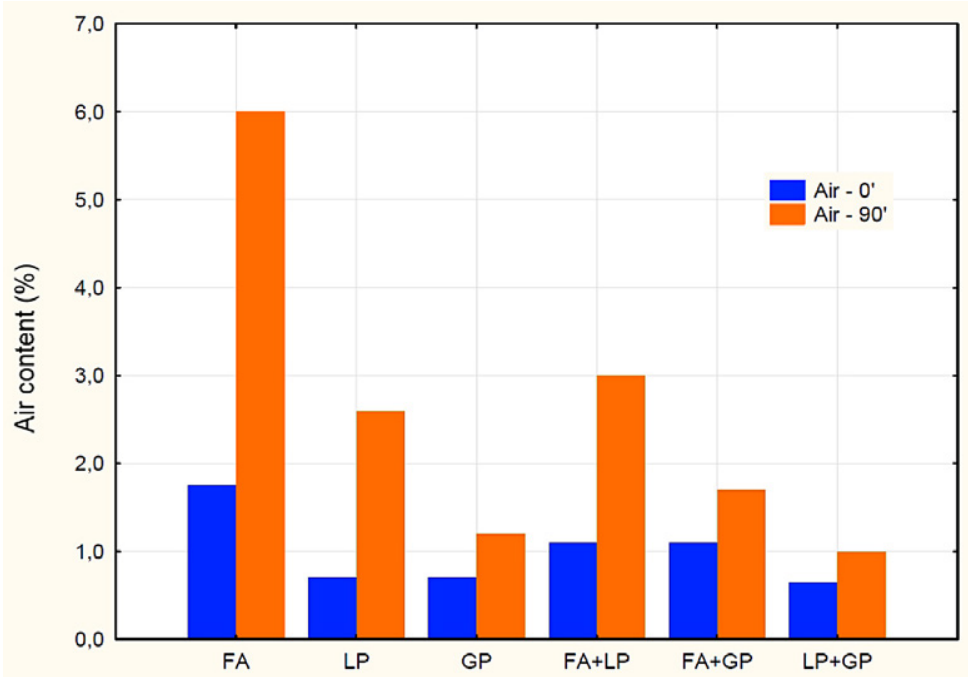

Figure 5. Air content in SCC concrete mixes immediately after mixing and after 90 minutes

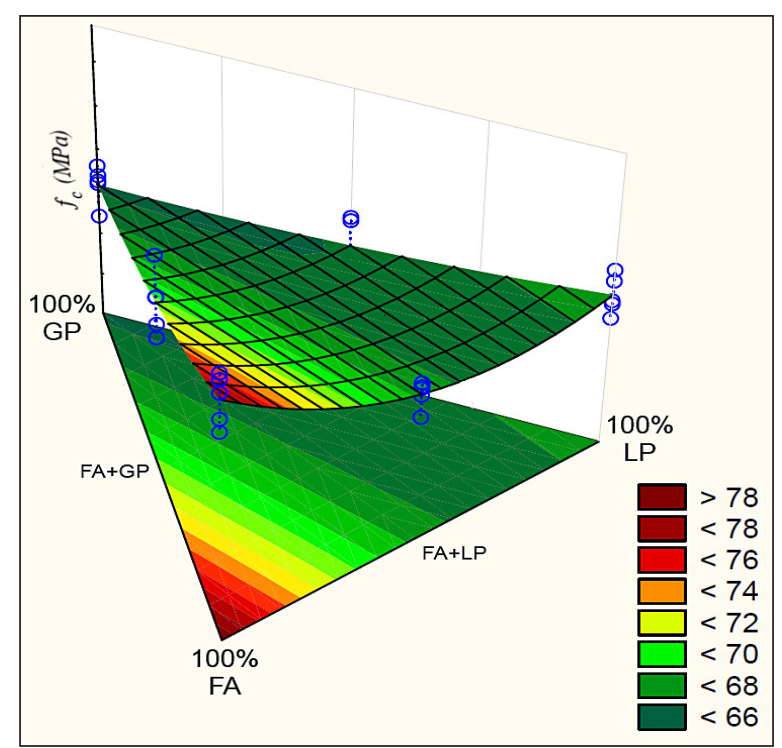

Figure 6. 28-day compressive strength results for self-compacting concretes diameters compared to those measured at time ' 0 ' amounted, respectively, to: $130 \mathrm{~mm}$ and $110 \mathrm{~mm}$, and after 90 minutes: $260 \mathrm{~mm}$ and $250 \mathrm{~mm}$. In terms of flow over time (Figures 1 and 4 ) the most stable were the concrete mixes with fly ash (FA) and granite powder (GP).

Apart from the adverse effect of the limestone powder additive on flow stability of the concrete mix, quite clearly found in the conducted tests, also the aspect of combined use of GP and FA seems to deserve further research. The seemingly inactive ingredient, that is granite powder, affected stability of mixes containing fly ash, but the reason for this effect is difficult to establish on the basis of investigation carried out. Chemical effect in this case cannot be excluded, but there is insufficient evidence in the literature to allow putting forward such a hypothesis. 
Table 2. Binder $\left(b_{i}\right)$ and carbon $\left(c_{i}\right)$ intensity indexes based on average compressive strength values

\begin{tabular}{|l|c|c|c|c|c|c|c|}
\hline \multicolumn{1}{|c|}{ Characteristic } & Unit & FA & LP & GP & FA+LP & FA+GP & LP+GP \\
\hline $\begin{array}{l}\text { Compressive strength } \\
\text { (average) }\end{array}$ & $\mathrm{MPa}$ & 78.9 & 68.0 & 65.8 & 67.7 & 70.4 & 66.1 \\
\hline Binder intensity, $\mathrm{b}_{\mathrm{i}}$ & $\mathrm{kg} / \mathrm{m} / \mathrm{MPa}$ & 4.4 & 5.2 & 5.3 & 5.2 & 5.0 & 5.3 \\
\hline Carbon intensity, $\mathrm{c}_{\mathrm{i}}$ & $\mathrm{kg} / \mathrm{MPa}$ & 3.3 & 3.8 & 3.9 & 3.8 & 3.7 & 3.9 \\
\hline
\end{tabular}

Table 3. Qualitative evaluation of each SCC series depending on different test characteristics

\begin{tabular}{|l|c|c|c|c|c|c|}
\hline \multicolumn{1}{|c|}{ Characteristic } & FA & LP & GP & FA+LP & FA+GP & LP+GP \\
\hline $\mathrm{T}_{500} 0^{\prime}$ & $0+$ & $0+$ & $0+$ & $0+$ & $0+$ & $0+$ \\
\hline $\mathrm{T}_{500} 90^{\prime}$ & + & 0 & - & -- & + & 0 \\
\hline $\mathrm{D}_{\max } 0^{\prime}$ & $0+$ & $0+$ & $0+$ & $0+$ & $0+$ & $0+$ \\
\hline $\mathrm{D}_{\max } 90^{\prime}$ & 0 & - & ++ & -- & 0 & + \\
\hline $\mathrm{D}_{\max }$ lost & ++ & - & ++ & - & - & 0 \\
\hline Air content 0' & 0 & ++ & ++ & + & + & ++ \\
\hline Air content 90' & -- & 0 & ++ & 0 & + & ++ \\
\hline $\begin{array}{l}\text { Compressive strength } \\
\text { intensity indexes }\left(\mathrm{b}_{\mathrm{i}}, \mathrm{c}_{\mathrm{i}}\right)\end{array}$ & ++ & 0 & 0 & 0 & + & 0 \\
\hline Total: + / & $7 / 2$ & $4 / 2$ & $10 / 1$ & $7 / 1$ & $6 / 1$ & $7 / 0$ \\
\hline Rank & 4 & 6 & 1 & 3 & 4 & 2 \\
\hline
\end{tabular}

Note: evaluation scale: + or ++ means good or very good quality of series, respectively;

- or -- means bad or very bad, respectively; 0 means acceptable quality.

All the concrete mixes had very low $(<2 \%)$ initial air content (measured directly after ingredient mixing). Addition of limestone or granite powder alone or in combination has proved to be particularly advantageous $(0.7 \%)$. Air content was much more differentiated after 90 minutes (Figure 5). The most extreme result, as high as $6 \%$, was measured in the mix with fly ash alone, and the use of granite powder alone $(1.2 \%)$ or in combination with limestone powder $(1 \%)$ proved very advantageous. This authorises a statement that GP positively affects the fundamental nominal property of self-compacting concrete, which is the self-deaeration ability. It is also the only mineral additive (of the three used) which is definitely inactive towards cement.

"Activity" of limestone powder, in turn, expressed in increased $\mathrm{T}_{500}$, reduced maximal diameter of slum-flow over time, and increased air content, was initiated after a longer time (after approximately 60 minutes).

The results of this study have been confirmed by observations of Grzeszczyk et al. [2006] and Grzeszczyk and Podkowa [2010]. They found that the self-compacting mixes including limestone powder show lower fluidity and higher air content as compared to those with fly ash used as the microfiller. However, when granite powder was used, the other interaction both with fly ash and limestone powder could be expected, which has been observed in case of series FA+GP and $\mathrm{LP}+\mathrm{GP}$ in this study taking account technological effect. Generally, it can be assumed that granite powder is an effective stabiliser, especially for negative influence over time of the limestone powder used as a microfiller. This conclusion is particularly important in the context of construction practice and performance. If fresh concrete has to be placed in construction after longer periods of time (later than one hour) the use of granite powder seems to be an optimal solution. For this type of microfiller the majority of rheological properties, as well as air content in fresh concrete are still within the acceptable range even after 90 minutes. Subjective evaluation (Table 3 ) proves this finding.

Compressive strength is recognised as a secondary property of self-compacting concrete. However, SCC reaches high values, usually exceeding $50 \mathrm{MPa}$. In the context of ecological aspects, more important is how to obtain concrete of good quality with minimal damage to environment at the same time. As it was stated earlier, the simplest way of evaluation that ability is to calculate binder intensity and carbon intensity indexes. In the presented studies, the most beneficial microfiller is fly ash with $b_{i}$ equal to $4.4 \mathrm{~kg} /$ $\mathrm{m}^{3} / \mathrm{MPa}$ and $\mathrm{c}_{\mathrm{i}}$ equal to $3.3 \mathrm{~kg} / \mathrm{MPa}$. It is far from 
the other cases of waste mineral additives used, very similar to each other $-b_{i}$ is within the range of 5.0-5.3 and $c_{i}$ of 3.7-3.9.

\section{CONCLUSIONS}

Test results presented in this paper and their analysis, along with background literature, lead to the following conclusions:

1. Efficacy of replacing pure clinker binder with waste mineral additives in self-compacting concretes is substantiated by both technological and environmental reasons.

2. All mineral additives used alone or in combination (fly ash, limestone powder and granite powder) have proven effective in achieving self-compactibility criteria by concrete mixes, as tested for time of up to 60 minutes.

3. The concrete mixes with fly ash and granite powder used alone had the best flow stability over time, while the mix with limestone powder had the worst stability, at time limit of 60 minutes.

4. Granite powder had the most stabilising effect on air content increase in the concrete mix, while fly ash had the smallest effect.

5. Chemical reaction between limestone powder used alone or with other waste mineral additives is probable, with an adverse effect on rheological properties of the concrete mix.

6. Taking into account both concrete compressive strength as well as calculated binder and carbon dioxide intensity indexes $\left(b_{i}\right.$ and $\left.c_{i}\right)$, the most favourable waste mineral additive used as a microfiller for SCC is fly ash. It is in contrary to the beneficial influence of granite powder as a microfiller (used alone and with limestone powder and fly ash) on SCC rheological properties.

7. For the purposes of hydrotechnical engineering, granite powder is the waste mineral additive most recommended for use in selfcompacting concrete. This is because concrete mixes made with its addition have satisfactory flow stability and because it has high technical value in terms of durability and strength. Use of fly ash, particularly alone, seems to be the least reasonable due to high decrease of selfdeaeration ability by concrete mixes over time.

8. Taking into consideration all tested properties of self-compacting concrete and performing subjective expert evaluation, it can be concluded that the most beneficial waste microfiller for SCC is granite powder.

9. Further research is required for the following issues:

- determining the synergy effect of several waste mineral additives used simultaneously, especially stone powders,

- testing rheological properties of concrete mixes at a later time (also after 120 minutes), which is important in production and placing processes.

\section{Acknowledgement}

The authors express sincere appreciation to M.Sc. Daniel Owsiak from Lafarge Poland for providing cement used in the studies and inspiring discussion on reducing $\mathrm{CO}_{2}$ emission in cement production.

\section{REFERENCES}

1. Aitcin P-C. 2000. Cements of yesterday and today. Concrete of tomorrow. Cement and Concrete Research, 30, 1349-1359.

2. Aruntas H.Y., Dayı M., Tekin I., Birgul R., Şimşek O. 2007. Effects of marble powder on the properties of self-compacting concretes. In: Proceedings of Second National Symposium on Chemical Admixtures Use in Structures, Ankara, 161-172.

3. Bromberek Z. 2012. Budownictwo zrównoważone w aspekcie trwałości. In: T. Błaszczyński (Ed.) Trwałość budynków i budowli. Dolnośląskie Wydawnictwo Edukacyjne, Wrocław.

4. Corinaldesi V., Moriconi G. 2008. Environmentally-friendly self-compacting concrete for rehabilitation of concrete structures. In: Proceedings of International Conference on Concrete Construction, London, 403-407.

5. Corinaldesi V., Moroconi G., Naik T. 2010. Characterization of marble powder for its use in mortar and concrete. Construction and Building Materials, 24, 113-117.

6. Damineli B.L., Kemeid F.M., Aguiar P.S., John V.M. 2010. Measuring the eco-efficiency of cement use. Cement and Concrete Composites, 32 (8), 555-562.

7. EN 197-1:2000. Cement, Part 1: Definitions, specifications and conformity criteria.

8. EN 197-2:2000. Cement, Part 2: Conformity evaluation.

9. EN 12620:2002. Aggregates for concrete. 
10. EN 12350-7:2009. Testing fresh concrete. Air content. Pressure methods.

11. EN 12350-8:2009. Testing fresh concrete - Part 8: Self-compacting concrete - Slump-flow test.

12. EN 12390-3:2009. Testing hardened concrete Part 3: Compressive strength of test specimens.

13. EN 450-1:2010. Fly ash for concrete. Definition, specifications and conformity criteria.

14. Felekoğlu B., Tosun K., Baradan B., Altun A., Uyulgan B. 2006. The effect of fly ash limestone fillers on the viscosity and compressive strength of self-compacting repair mortars. Cement and Concrete Research, 36, 1712-1726.

15. Giergiczny Z., Garbacik A., Pużak T., Sokołowski M. 2010. Cementy portlandzkie wieloskładnikowe CEM II/B-M (V-LL) 32,5R i CEM II/B-M (S-V) 32,5 R - właściwości i zastosowanie. Konferencja Dni Betonu, Wisła, 155-163.

16. Grabiec A.M. 2013. Influence of viscosity modifying agent on some rheological properties, segregation resistance and compressive strength of selfcompacting agent. Journal of Civil Engineering and Management, 19 (1), 1-8.

17. Grzeszczyk S., Janowska-Renkas E., Skaliński B. 2006. Właściwości reologiczne mieszanek samozagęszczalnych - wpływ wypełniaczy. Cement Wapno Beton, 6, 337-342.

18. Grzeszczyk S., Podkowa P. 2010. Wpływ mączki wapiennej na właściwości samozagęszczających się betonów. Cement Wapno Beton, 6, 340-347.

19. IPPC-5. IPPC Fifth Assessment IPPC Report: Climate Change 2013. www.climatechange2013.org/images/ report/WGI AR5_ALL_FINAl.pdf(15.04.2014).

20. Kaszyńska M. 2003. Beton samozagęszczalny rozwój technologii i wyniki badań. Konferencja Dni Betonu, Wisła, 1-16.

21. Kurdowski W. 2010. Chemia cementu i betonu, wyd. Stowarzyszenie Producentów Cementu, Kraków.

22. Liu Laibao, Zhang Yusheng, Zhang Wenhua, Liu Zhiyong, Zhang Lihua. 2013. Investigating the influence of basalt as mineral admixture on hydration and microstructure formation mechanism of cement. Construction and Building Materials, 448, 434-440.

23. Mądrawski J., Kostrzewski W. 2008. Ocena lepkości zapraw za pomocą wiskozymetru. Aparatura Badawcza. Tom XIII, (3), 13-18.

24. Meyer C. 2009.The greening of the concrete industry. Cement and Concrete Composites, 31 (8), 601-605.

25. Nepomuceno M., Oliveira l., Lopes S.M.R. 2012. Methodology for mix design of the mortar phase of self-compacting concrete using different mineral additions in binary blends of powders. Construction and Building Materials, 26 (1), 317-326.

26. Okamura H., Ouchi M. 2003. Self-compacting concrete development. Journal of Advanced Technology 1, 5-15.

27. Samer M. 2013. Towards the implementation of the Green Building concept in agricultural buildings: a literature review. Agricutural Engineering International: CIGR Journal, 15 (2), 25-46.

28. Szwabowski J., Gołaszewski J. 2010. Technologia betonu samozagęszczalnego betonu cementowego, wyd. Stowarzyszenie Producentów Cementu, Kraków.

29. Szwabowski J., Śliwiński J. 2003. Betony samozagęszczalne. Polski Cement, 2, 42-45.

30. Takada K., Pelova G.J., Walraven J.C. Influence of microfillers on proportioning of mortar in selfcompacting concrete. In: Proceedings of the First RILEM Int. Symposium on Self-Compacting Concrete, Stockholm, September 1999, 537-548.

31. Voltz J.S. 2012. High-volume fly ash concrete for sustainable construction. Advanced Materials Research, 512-515, 2976-2981.

32. WBCSD 2009. Cement companies reduce climate impacts by slowing $\mathrm{CO}_{2}$ emissions growth. World Business Council for Suistainable Development, Geneve, http://www.wbcsdcement.org/ index.php?option $=$ com_content\&task $=$ view\&id $=$ 163\&Itemid=171 (02.04.2014).

33. Woyciechowski P. Domieszki modyfikujące lepkość samozagęszczalnych mieszanek betonowych. Konferencja Dni Betonu, Wisła, 2006, 623-633. 